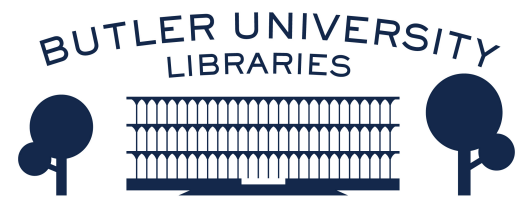

Journal of Hindu-Christian Studies

Volume 31 Celebrating Rāmānuja at 1000: The

Heritage and Promise of the Study of Rāmānuja

in a Christian-Hindu Comparative Theology

Article 26

2018

\title{
Writing, Living, and Editing Hindu-Christian Studies: Appreciation for Bradley Malkovsky's Contribution
}

Michelle Voss Roberts

President of the Society for Hindu-Christian Studies

Follow this and additional works at: https://digitalcommons.butler.edu/jhcs

\section{Recommended Citation}

Roberts, Michelle Voss (2018) "Writing, Living, and Editing Hindu-Christian Studies: Appreciation for Bradley Malkovsky's Contribution," Journal of Hindu-Christian Studies: Vol. 31, Article 26.

Available at: https://doi.org/10.7825/2164-6279.1703

The Journal of Hindu-Christian Studies is a publication of the Society for Hindu-Christian Studies. The digital version is made available by Digital Commons @ Butler University. For questions about the Journal or the Society, please contact cbauman@butler.edu. For more information about Digital Commons @ Butler University, please contact digitalscholarship@butler.edu. 


\title{
Writing, Living, and Editing Hindu-Christian Studies: Appreciation for Bradley Malkovsky's Contribution
}

\author{
Michelle Voss Roberts \\ President of the Society for Hindu-Christian Studies
}

I initially encountered Dr. Bradley Malkovsky when, as a graduate student, I presented my first paper with the Society for HinduChristian Studies, and he encouraged me to submit it for publication in the Journal of Hindu-Christian Studies. He has performed this role of cultivating new scholars in the field over his sixteen years as editor of the JHCS. Now, as he steps down from the editorship, a look back on his contribution to the field thus far reveals a remarkable trajectory of scholarship and service to the institutions that make Hindu-Christian studies a thriving academic community.

As a member of the founding Board of Directors of the Society for Hindu-Christian Studies in 1994, Malkovsky and his peers envisioned "a scholarly society dedicated to the study of Hinduism and Christianity and their interrelationships." Through its journal and annual conferences, the Society would "create a forum for the presentation of historical research and studies of contemporary practice [and] for the fostering of dialogue and interreligious conversation, carried forward in a spirit of openness, respect and true inquiry." "In 2002, Malkovsky became the second editor/treasurer of the HinduChristian Studies Bulletin (which became the Journal of Hindu-Christian Studies in 2004), after Harold Coward had served in the role for fourteen years. In 2018, upon passing the editorial torch to Gopal Gupta, he continues as Treasurer of the Society.

Malkovsky is also Associate Professor of Comparative Theology at the University of Notre Dame, where he has been a member of the faculty since 1992. Previously, he taught systematic theology for two years at his alma mater, St. John's University in Collegeville, MN. Before that, his graduate studies took him abroad. He earned his M.A. and Ph.D. in Systematics at Universität Tübingen in Germany (1983, 1994), and he wrote his dissertation while studying for five years at the Centre for Advanced Studies in Sanskrit at the University of Poona (Pune, India).

\section{Scholar of Śankkara}

As highlighted in Reid Locklin's essay in this volume, many know Malkovsky primarily

Michelle Voss Roberts is Principle and Professor of Theology at Emmanuel College. An expert in comparative theology, with a particular focus on Christian and Hindu contexts, Voss Roberts has also written widely about aesthetics, gender, and embodiment. Her teaching integrates the study of Christian theological traditions with theories of gender and sexuality, disability studies, and religious pluralism. Her recent publications include, Dualities: A Theology of Difference (2010), Tastes of the Divine: Hindu and Christian Theologies of Emotion(2014), and Body Parts: A Theological Anthropology (2017). She has also edited a volume of essays for the introductory theology classroom, Comparing Faithfully: Insights for Christian Systematic Theology (2016). 
as an important scholar of Śankara, the eighth-century figure whose commentaries on Vedānta texts established him as the founder of the Advaita school. Malkovsky's collaborations as editor of the volume, New Perspectives on Advaita Vedānta, highlight how these studies have changed so that Śankara is now understood in relation not only to his later exegetes, but also in relation to other earlier Indian schools of thought and to various contemporary intercultural and interreligious considerations. ${ }^{2}$ His own scholarship has facilitated these shifts.

As an important contribution to these changes in Śankara studies, his 2001 book, The Role of Divine Grace in the Soteriology of Samkarācārya, participates in the twentiethcentury reassessment of the great teacher's thought. It defends several strong claims that go against the grain of much received interpretation, particularly regarding the personalistic element of Śankara's Absolute (amplifying Paul Hacker), and Śankkara's realism (building on Richard De Smet, whom the aforementioned edited volume commemorated). ${ }^{3}$

The unique contribution of this book is the case it builds for the importance of grace (prasāda, anugraha) in Śankara's corpus by reading backwards for historical connections-to the earlier Vedanta teachings of Adiśeșa, Nimbarka, and others-rather than interpreting Śankara in ways that anticipate the developments of the later Advaita school, as many of Malkovsky's predecessors have done. Through this approach, he discovers a "welding of theistic [namely, Vaișnavite] and non-dualistic visions of life," ${ }^{4}$ including evidence that "Śamkara tends to identify the grace-giving Lord with the highest reality."

Malkovsky traces teachings about divine grace across Śankara's corpus which, though unsystematic, nevertheless show that for him grace is "indispensable for liberation." As Malkovsky explains juxtapositions that remain unresolved in Śańkara's work,

[W]e learn that Śamkara has not one but two theologies of freedom, and that he has not resolved the tension between them, although both share important elements .... [and] the compatibility of liberationthrough-knowledge with liberationthrough-grace. The first is always primary in Śamkara's thought, yet the second turns out to be indispensable.

The result of this dive into these tensions is a serious look at Śankara's teaching about grace. Although this doctrine "is nothing akin to the Protestant Christian teaching of sola gratia"-after all, liberation comes primarily through knowledge-it is substantial nonetheless. ${ }^{8}$ For Śankara, grace is threaded through a person's preparation for liberation in the forms of scripture, one's teacher, and the desire for liberation itself; and the sädhaka's final illumination is finally due to the impartial grace of the Lord.

Malkovsky's preparation in Catholic and ecumenical theologies, though not immediately evident in the published version of this project, contributes important sensitivities to its rereading of Śankkara. The comparative sections of the earlier dissertation do not appear in the monograph. Nevertheless, he raises the sorts of questions that abound in Christian theology, and in Catholic-Protestant polemics in particular, about the relative weight of divine grace in relation to human effort. ${ }^{9}$ His careful textual study allows him to search for evidence of grace in Śankara's thought, but this agenda does not overdetermine his interpretation of the great teacher. The contours of the debates he discovers there cannot be reduced to whatever parallels one might recognize in Christian discussions. Indeed, he follows 
Śankara into nuanced treatments of issues that lack direct correlates: the relation of divine grace to yogic powers (siddhis) gained on the way to liberation, divine impartiality in relation to human freedom and karma, and the grace of the teacher and scripture. By pursuing the topic of grace, his line of questioning allows him to tease out nuances related to an important role for grace and a personal deity that does not automatically dissolve into a "higher," non-personal Absolute, which other scholars had neglected.

\section{Comparative Theologian}

Malkovsky's rethinking of Śankkara from an Indological angle is already a contribution to Hindu-Christian Studies, as Reid Locklin has argued in this issue. However, readers of this journal will also know Malkovsky as a comparative theologian whose religious and interreligious concerns animate his scholarly trajectory explicitly.

Among the many topics Malkovsky has illuminated through a comparative approach are the diverse views of Christ in Hinduism, ${ }^{10}$ questions raised at the confluence of teachings about reincarnation and purgatory, ${ }^{11}$ theologies of the infinite, ${ }^{12}$ cosmic and historical revelation, ${ }^{13}$ and interpretations of the Lord (Íśvara) in the Yoga Sutras and the teachings of B. K. S. Iyengar in comparison with Christian understandings of God.

Take, for example, his mapping of a range of views of God, divine grace, and religious practice in the latter project. Emphases on divine love, the eschatological completion of the human person, and moral accountability to God set Christian teaching apart from both of the yogic traditions Malkovsky surveys here. However, although devotion to İśvara is only an optional aid in the Yoga Sutras, this role has grown in some schools, so that "in some respects Mr. Iyengar's understanding of God is closer to the Christian understanding of a supreme transcendent reality than it is to the Lord of the YS" in its "personal and gracegiving" character. ${ }^{14}$ Malkovsky also notes that something like a "healthy dualism" can be affirmed in both traditions, which recognizes that "all is not well with the body" and that "we are a reality that transcends our own body." 15 Without attempting to reconcile the differing metaphysics and anthropologies, Christians who practice yoga can affirm two kinds transcendent experience: both the devotional/relational experience of union with God and the yogic/non-relational experience of transcendence that passes beyond self-centeredness.

One often witnesses in Malkovsky's choice of topics a willingness to paint with a broader brush than other comparative theologians. He writes in defense of this methodological choice,

One of the things notably amiss in the work of much comparative theology today is an almost exclusive and excessive attention to the particular, especially its emphasis on individual texts, to the point that anything like the broad fundamentals of a religion are overlooked. I think this is a mistake. The fact is, almost all Hindus do believe in reincarnation ... they are therefore dualistic in their anthropology, and they do not subscribe to individual or cosmic transformation in a future eschaton. ${ }^{16}$

Methodologically, then, Malkovsky differs from a comparative theologian like Francis X. Clooney, who prefers fine-grained textual analysis over general patterns.

Nevertheless, Malkovsky's projects exemplify the kind of study Clooney has recently hailed as the future of HinduChristian Studies: a scholar-practitioner's contributions that are "intellectually and spiritually compelling on all sides." ${ }^{17}$ In an 
early article, "Advaita Vedanta and Christian Faith," Malkovsky anticipates this combination of the intellectual and spiritual when he compares Richard De Smet, S.J., who emphasized intellectual encounter, with Abhishiktananda, who pursued experiential points of contact to argue "that both approaches are viable and necessary for an indepth encounter between Advaitins and Christians." 18

\section{Seeker of Interreligious Wisdom}

Malkovsky's global travels occurred within a timeframe when it was possible to sit at the feet of some of the greatest twentiethcentury Christian theologians of religious pluralism. In Tübingen, he studied with leading ecumenical thinkers such as Walter Kasper, Hans Küng, and Gerhard Lohfink. He stayed during his dissertation studies at Bede Griffiths's Saccidananda Ashram and with the sisters at the C.P.S. Ashram in Pune-settings which supported his concurrent explorations in Sanskrit, yoga, and vipassana meditation. This scholarly itinerary included both intellectual and spiritual points of contact between Hindu and Christian traditions.

It was during this time that he also formed a relationship with a Sunni Muslim family that led to his marriage to their daughter Mariam. A sense of the sacredness of the personal encounter emerges in his reflections on interfaith friendship:

During moments of deep personal exchange, I become aware that I am in the presence of God who surrounds us and blesses us. Our friendship is therefore a gift of God, a reminder of God's presence to all, and a reminder that God is greater than our religions, even when our faith traditions rightly seek to honor God and call us to submit to the divine will, which is Love. ${ }^{19}$
The personal dimensions of his story appear most vividly in God's Other Children: Personal Encounters with Faith, Love, and Holiness in Sacred India (HarperOne, 2013), a project that received the Huston Smith Prize from the HarperOne publishing company. Like another classic text for the classroom, Diana Eck's Encountering God, Malkovsky's skillful conversational style makes religious encounters come alive on the page. ${ }^{20}$ The engaging narrative of his adventures in India introduces readers to important features of India's religions in a remarkably accessible manner. For example, as he describes how he came to study yoga amid certain Christian objections to the practice, he peppers his response to criticisms with such engaging anecdotes that the reader is barely aware that she is being schooled in the limbs of yoga.

In several passages of the memoir, Malkovsky articulates the theological motivations for his ongoing study of the world's faith traditions:

To be sure, I had expected to find goodness among the followers of other religions as well as a sincere search for spiritual liberation, but I was surprised to find just how much more was already there waiting to be discovered. What I did not know was that for centuries Hinduism, Buddhism, and Islam had produced a multitude of saints and holy sages, a wisdom of the greatest depth, and countless miracles. All this has become for me a sign that God is very much at work in those religions, using them as vehicles of His power and grace.

But my new awareness of the greatness of other religions has also raised many questions about the relation of those religions to Christ and to Christianity, questions having to do especially with Christ's universal lordship and authority, 
how to best express his salvific meaning, and the proper way to witness to him in my encounter with Hindus, Buddhists and Muslims. The more I have wrestled with these issues, the more certain I've become that witnessing to Christ must also involve my readiness to learn how God is already present and working in the lives of people of other faiths. I therefore think that what is most important in this era of human history, a time in which religious traditions are interacting with each other like never before, is that we open ourselves to the truth and beauty of other faiths in a living, respectful, and receptive encounter. $^{21}$

This receptive and discerning spirit is on display in many of Malkovsky's other writings on interfaith understanding. Take, for instance, his discussion of Swami Vivekananda and Fr. Bede Griffiths. Both exemplify an openness to the genuine religious experiences in other traditions, even as they rank these experiences according to "the a priori acceptance of [their] religion's foundational revelation as normative ... [and] the personal experience of the Absolute mediated to them by their tradition." ${ }^{22}$ In dialogue with them, Malkovsky urges deeper knowledge of other traditions so that a posteriori theologies of religions may also be accountable to the selfdescriptions and complexities of those traditions.

In recent years, Malkovsky has contributed constructively to Catholic theologies and practices in relation to religious diversity. ${ }^{23}$ In a volume honoring Griffiths, he imagines a future "Vatican III," which might acknowledge revelation in other religions: "Perhaps Father Bede anticipated such a future Council when he repeatedly challenged his listeners to consider the possibility that God has revealed Godself in multiple ways to the world with Christ always remaining at the center." ${ }^{24}$ Since the Second Vatican Council, Catholic theologians such as Jacques Dupuis have explored how to hold the centrality of Jesus Christ alongside this multiplicity. Malkovsky adds his voice by positing a complementarity of cosmic and historical revelations in Griffiths' teachings: cosmic revelation "is to be found potentially everywhere in the world" through an intuited "interior unity of being and consciousness" in "nature and the soul," while the historical revelation is found in events that show the value of the finite world, embodied persons, and living societies. ${ }^{25}$ Adherents of traditions that primarily emphasize one of these dimensions might benefit from encounter with the other basic experience of revelation.

\section{An Enduring Legacy for the Field}

Bradley Malkovsky's editorship of the Journal of Hindu-Christian Studies leaves a considerable legacy for the field. He has graciously invited newer scholars into the field and shaped their development through the peer review process. He has been especially keen to reach an Indian audience and invite articles from Indian scholars. These efforts have made this scholarship available to an audience spanning North America and India-first in print and now in digital format.

Under his leadership, the JHCS has grown, averaging seven or eight articles and ten book reviews per year. The substantial book reviews, often in the range of one thousand words, have proven to be a popular feature for online downloads. Recent issues have fostered lively discussion of topics from contemplative traditions (2014) to aesthetics (2015) to God and evil (2016). This editorial work culminated in a special issue in 2017, which includes color photographs and additional articles and reviews. Focusing on a topic dear to his heartYoga and God-this final issue from 
Writing, Living, and Editing Hindu-Christian Studies: Appreciation for Bradley Malkovsky's 99

Malkovsky's tenure extends the conversation begun in his own scholarship and in the 2012 issue. The thoughtful unfolding of the topic encompasses both the recent objections to the appropriation and commercialization of yoga as well as the enduring value of practicing yoga for Christians who may still wrestle with the compatibility of its teachings with their faith.

As editor for the past sixteen years, then, Malkovsky has had the crucial function of amplifying the "dialogue and interreligious conversation, carried forward in a spirit of openness, respect and true inquiry" that characterizes the best of Hindu-Christian Studies and the aspirations of this journal. Certainly, the product itself, which boasts subscribers across the globe and offers free access to much of its content to non-

\section{Notes}

1 Society for Hindu-Christian Studies. https://digitalcommons.butler.edu/jhcs/about.ht $\underline{\mathrm{ml}}$

${ }^{2}$ Bradley J. Malkovsky, ed., New Perspectives on Advaita Vedānta. Commemoration Volume for Richard De Smet, S.J. (Leiden: E. J. Brill, 2000).

${ }^{3}$ Bradley J. Malkovsky, The Role of Divine Grace in the Soteriology of Samkarācārya (Leiden: Brill, 2001), xiii.

${ }^{4}$ Ibid, xii.

${ }^{5}$ Ibid., xiv. Cf. Bradley J. Malkovsky, "The Personhood of Śamkara's Para Brahman," Journal of Religion (1997), https://doi.org/10.1086/490065.

${ }^{6}$ Malkovsky, The Role of Divine Grace in the Soteriology of Śamkarācārya, xi.

${ }^{7}$ Ibid., xvi.

${ }^{8}$ Ibid., 380.

${ }^{9}$ Ibid., xvii.

10 Bradley Malkovsky, "Christ in Hinduism: Traditional Views and Recent Developments," in Alternative Christs, ed. Olav Hammer (Cambridge: Cambridge University Press, 2009).

${ }^{11}$ Bradley Malkovsky, "Belief in Reincarnation and Some Unresolved Questions in Catholic subscribers, advances conversation between Hindus and Christians. More significantly for those who know him, Bradley himself embodies the spirit of the publication. He gathers high quality contributions in the pursuit of "true inquiry," but always with a personal touch. He values the opportunity to reach out to subscribers, including (as I can attest) the occasional gentle reminder to renew whenever a subscription has lapsed. The importance of personal relationships visible in his memoir extends into his leadership of the Society, often behind the scenes. Bradley's kindness and habitual posture of friendship admirably sets the tone for the rest of us who continue alongside him in the ongoing work of Hindu-Christian studies.

Eschatology," Religions 8

(2017),

https://doi.org/10.3390/rel8090176.

12 Bradley Malkovsky, "The Mystery of the Infinite in the Hindu Spirituality of Non-Duality: Some Observations from a Christian Perspective," in Finding Beauty in the Other, ed. Peter Casarella and Mun'im Sirry (South Bend, IN: University of Notre Dame Press), 2017.

${ }^{13}$ Bradley Malkovsky, "On the Distinction of Cosmic and Historical Revelation: Its Value and Limitations," in The Continuing Quest: Carrying Forward the Contemplative and Prophetic Vision of Bede Griffiths, ed. Thomas Matus and Joseph Wong (Erzabtei St. Ottilien: Eos Verlag, 2016), 4364.

14 Bradley Malkovsky, "God in Yoga and Christianity," Journal of Hindu-Christian Studies, 30 (2017): 35, https://doi.org/10.7825/2164$\underline{6279.1657}$.

${ }^{15}$ Ibid., 41.

${ }^{16}$ Malkovsky, "On the Distinction of Cosmic and Historical Revelation," 63.

${ }^{17}$ Francis X. Clooney, The Future of HinduChristian Studies (London and New York: Routledge, 2017), 112. 
${ }^{18}$ Bradley Malkovsky, "Advaita Vedanta and Christian Faith," Journal of Ecumenical Studies (1999): 397.

${ }^{19}$ Bradley J. Malkovsky, "Rasoul, My Friend and Brother," in Interreligious Friendship after Nostra Aetate, ed. James L. Fredericks and Tracy Sayuki Tiemeier (New York: Palgrave Macmillan, 2015), 95-96.

${ }^{20}$ Cf. Diana L. Eck, Encountering God: A Spiritual Journey from Bozeman to Banaras (Boston: Beacon, 1993).

${ }^{21}$ Bradley Malkovsky, God's Other Children: Personal Encounters with Faith, Love, and Holiness in Sacred India (San Francisco: HarperOne, 2013), 267-268.

${ }^{22}$ Bradley Malkovsky, "Swami Vivekananda and Bede Griffiths on Religious Pluralism: Hindu and Christian Approaches to Truth," Horizons 25.2 (1998), 235 , https://doi.org/10.1017/s0360966900031169.

${ }^{23}$ Bradley Malkovsky, "The Princess Who Lived Under a Tree," Dilatato Corde V.2 (July-December 2015; publication of the Christian Monastic Interreligious Dialogue); and Bradley Malkovsky, "Nostra Aetate: Declaration on the Relation of the Church to Non-Christian Religions," in A Liturgical Companion to the Documents of the Second Vatican Council.Chicago: Liturgy Training Publications, 2016, 103-107.

${ }^{24}$ Malkovsky, "On the Distinction of Cosmic and Historical Revelation," 46-47.

${ }^{25} \mathrm{Ibid} ., 52-53$. 